\title{
Trademark Protection in Ethiopia Vis-a-vis TRIPs: A Closer Look to the Requirements of Protection \& Exclusive Rights of the Owner
}

\author{
Endryas Tekalegn \\ College of Law, Diredwa University , Diredawa Ethiopia
}

\begin{abstract}
Although the contribution and share of intellectual property rights to the country's economic growth is not paramount as of today, the Ethiopian Trade mark system has established a protection of Trade mark up on enacting trade mark proclamation. Similarly, as Ethiopia is on the move of to Acceding to World Trade Organization (WTO), the compatibility of Trade mark Proclamation with the TRIPs system is crucial.Therefore, this writing will scrutinize the system of trade mark protection in Ethiopia in line with TRIPs agreement and argues that despite there are some points which need consideration, the Ethiopian trademark proclamation is compatible and there are even TRIPS plus provisions in it which thereby the negotiating team of the country has nothing to worry on its accession to WTO as far as Trade mark Proclamation is concerned.
\end{abstract}

Keywords: TRIPS, Paris Convention, Well Known Mark, WTO

DOI: $10.7176 / \mathrm{JLPG} / 90-01$

Publication date:October $31^{\text {st }} 2019$

\section{Introduction}

The governing law on trademarks in Ethiopia is the Trademark Registration and Protection Proclamation which is meant to "protect the reputation and goodwill of business persons engaged in the manufacture and distribution of goods as well as services by protecting trademarks to avoid confusion between similar goods and services." 1

This is sought to be accomplished by defining a trademark as "as any visible sign capable of distinguishing goods or services of one person from those of others persons...", ${ }^{2}$ by providing an indicative list of such visible signs which may be used as a trademark and through a system of protection based on registration by stipulating that ownership rights of a trademark can be acquired and be binding on third parties upon the grant of a trademark registration certificate. ${ }^{3}$

This raises question whether the definition is compatible with the TRIPS ${ }^{4}$ system of trademark protection, and whether other types of signs which are not visible are protected in Ethiopia or not.

It is also justifiable to ask for what would be the fate of well known (famous marks) given the system of trademark protection is based on registration as indicated under Article 4 of the proclamation and despite Article 18 of the proclamation provides about the system of protection of well known marks in Ethiopia.

In addition, compatibility of the provisions dealing with collective mark and well known mark under the proclamation with that of TRIPS system will be analyzed. In addition, the requirements of protection of trade mark and the exclusive rights of the owner will be discussed.

In doing so, this writing will have five parts. Part I will discuss the concept of trademark of trademark and the justifications there to. Part II will discuss on subject matter protected. Part III then discusses the requirements for protection. And the final Part IV will discuss the exclusive rights of the owner of trade mark. Finally part V provides conclusion and recommendation.

\section{The concept and justification of trade mark protection}

Our life is surrounded by brands we recognize a fast food restaurant from a quick look at the golden arches on the red background. We don't call our Smartphone a "phone", but call it "I Phone" or "BlackBerry" or "Huawei" or "Samsung" and very well understand that "Apple" is not a fruit. And behind this diversity of recognized logo types and brand names stands a developed system of law, which ensures that recognized and distinctive brands are worth creating and investing money in their protection. That is the law of trade marks. ${ }^{5}$

A trademark is a sign capable of distinguishing the goods or services produced or provided by one enterprise from those of other enterprises.

\footnotetext{
Trademark Registration and Protection Proclamation No. 501/2006, Preamble [here in after called the proclamation or trademark proclamation interchangeably ]

${ }^{2}$ Id Article 2/12

${ }^{3}$ Id Article 4

4 Agreement on the Trade-Related Intellectual Property Rights, annex 1(c) of the (Marrakesh) Agreement ,January 1,1995 [here in after called TRIPS]

${ }_{5}^{5}$ Property rights protection and private sector development in Ethiopia, Elias N. Stebek, Muradu Abdo \& Hailu Burayu, Ethiopian Chamber of Commerce (ECCSA) and Swedish Agency for International Development Cooperation (SIDA), Dec.2013, Addis Ababa
} 
Any distinctive words, letters, numerals, drawings, pictures, shapes, colors, logotypes, labels or combinations used to distinguish goods or services may be considered a trademark. In some countries, advertising slogans are also considered trademarks and may be registered as such at national trademark offices. ${ }^{1}$

Unlike our proclamation which defines trademark as any visible sign capable of distinguishing goods or services, the Australian Trade Marks Act stats that sign:

"includes the following or any combination of the following, namely, any letter, word, name, signature, numeral, device, brand, heading, label, ticket, aspect of packaging, shape, color, sound or scent."

The US, defines a trade mark as including "any word, name, symbol, or device, or any combination thereof ... to identify and distinguish his or her goods, including a unique product, from those manufactured or sold by others and to indicate the source of the goods." ${ }^{3}$

Trademarks can be protected throughout the European Union (EU) by registering the mark as a community Trademark with the office for harmonization in the internal market (OHIM). This statutory right is governed by the Community trademark regulation (CTMR) ${ }^{4}$ which is harmonized across the European Union through the EU Trademark directive (TMD) ${ }^{5}$

According to Article 2 of the TMD and Article 4 of the CTMR:

A Trade mark may consist of any sign capable of being represented graphically, particularly words including personal names, designs, letters, numerals, the shape of goods or of their packaging, provided that such signs are capable of distinguishing the goods or services of one undertaking from those of other undertakings

This shows that an increasing number of countries allow for the registration of less traditional forms of trademarks such as single colors, three-dimensional signs (shapes of products or packaging), audible signs (sounds) or olfactory signs (smells). However, many countries have set limits on what can be registered as a trademark, generally only allowing for signs that are visually perceptible or that can be represented graphically. ${ }^{6}$

And from this it can be said that New technologies and innovations have created new categories of trademarks, differing from conventional trademarks that traditionally consist of letters, numerals, words, logos, pictures, symbols or a combination there of. This new category is called' non-conventional trademarks' or also 'non-traditional trademarks'. Such trademarks can be visible signs, e.g. three-dimensional marks, colour marks, holograms, motion or multimedia signs, position marks, gesture marks, or non-visible signs, e.g. sound (aural) marks, smell marks( olfactory), taste marks( gustatory), and textural( feel) mark. ${ }^{7}$

Though Trademark is categorized as conventional and non conventional, or traditional and nontraditional trademark as pointed out above; there are types of marks forming part of trade mark. These includes the Trademark (Marks used to distinguish certain goods as those produced by a specific enterprise), Service marks (Marks used to distinguish certain services as those provided by a specific enterprise), Collective marks (Marks used to distinguish goods or services produced or provided by members of an association), Certification marks (Marks used to distinguish goods or services that comply with a set of standards and have been certified by a certifying authority) and well known marks (Marks that are considered to be well-known in the market and as a result benefit from stronger protection). ${ }^{8}$

The main function of a trademark is to enable consumers to identify a product (whether a good or a service) of a particular company so as to distinguish it from other identical or similar products provided by competitors. Consumers who are satisfied with a given product are likely to buy or use the product again in the future. For this, they need to be able to distinguish easily between identical or similar products.

The justification of trademark protection therefore; though not generally far away from the justifications of intellectual property, and despite there are scholars who rules out the protection of trademark as creation just like inventions and literary and artistic works, trademark protection necessitates because by enabling companies to differentiate themselves and their products from those of the competition, trademarks play a pivotal role in the branding and marketing strategies of companies, contributing to the definition of the image, and reputation of the company's products in the eyes of consumers. ${ }^{9}$

\footnotetext{
${ }^{1}$ Intellectual property for business series No 1, An introduction to trademarks for small and medium-sized Enterprises, World intellectual property organization WIPO publication No 900, 2017

${ }^{2}$ Section 6 of the Australian Trade Marks Act 1995 (No. 119)

${ }^{3}$ The Lanham Act, s 45

${ }^{4}$ Community Trade Mark Regulation [EC] No 40/94

${ }^{5}$ The First Council Directive of 21st December 1988 89/ 104/ EEC (Directive)

${ }^{6}$ See Vatsala Sahay Conventionalising Non-Conventional Trademarks of Sounds and Scents: A Cross-jurisdictional Study, Nalsar Student Law Review page 128-141, 2011; see also Praveen Pani \& Anant Puranik Non-Conventional Trademarks, IPpro Services (India) Pvt. Ltd, 2009

${ }^{7}$ Ramzi Madi, Colour and Sound Marks: A Brief Overview of Civil Protection in Light of Jordanian Legislation, Arab Law Quarterly, Vol. 24, No. 1 (2010), pp. 41-72 http://www.jstor.org/stable/40604791 Accessed: 11-02-2019

${ }^{8}$ See Making a mark, An introduction to trade marks for small and medium-sized enterprises, Intellectual property for business series No. 1, World intellectual property office, 2006

9 Id page 4-5
} 
The image and reputation of a company then create trust which is the basis for establishing a loyal clientele and enhancing a company's goodwill. Consumers often develop an emotional attachment to certain trademarks, based on a set of desired qualities or features embodied in the products bearing such trademarks.

An author called Michael Spence argued also that the protection of Trademark is also protection of the trader against the use of signs that involve, not confusion with a registered trade mark, but rather allusion to the registered mark. ${ }^{1}$

According to Landes and Posner's "search costs" theory, trademarks have value because they reduce consumer search costs and thus promote overall efficiency in the economy. Over the past two decades, the search costs theory of trademark law has attracted a substantial following among both commentators and courts. ${ }^{2}$ Thus in economic terms, trademarks contribute to economic efficiency by reducing consumer search costs.

\section{Subject matters protected}

As pointed out above Article 2/12 of the proclamation ${ }^{3}$ defines trademark as: 'any visible sign capable of distinguishing goods or services of one person from those of other persons; it includes words, designs, letters, numerals, colors, or the shape of goods or their packaging or the combination thereof.

\section{1. visible signs}

This quoted provision of the proclamation provides a broad definition of the subject matter of trademarks in Ethiopia. The examples provided are not exhaustive. Therefore, "any visible sign capable of distinguishing goods or services" would be able to gain protection under the law even if it is not one of those signs enumerated under such provision. Article 5/1/ of the proclamation reiterates that "any trademark that is capable of clearly distinguishing goods or services" is able to receive protection.

It also seems that the use of the word "colors" in plural form under Article 2/12/ last statement of the proclamation seem that a single color is ruled out as a trademark and what seems to be permitted is the use of a combination of two or more colors.

However, when we see the reading of Article 5/2/ of the proclamation, it provides that a trademark may be registered in black-and white or color. This shows that a single color by itself may be subject of protection.

\subsubsection{Non visible signs: Should they really be excluded?}

The question now is whether the trademark proclamation rules out use of non-visible signs such as sound (aural) marks, smell marks (olfactory), taste marks (gustatory), and textural (feel) marks? If yes, is such exclusion compatible with the TRIPS system?

Looking to Article 2/12/ of the proclamation it seems that the proclamation rules out of non-visible signs such as sound (aural) marks and smell marks (olfactory).

This is implied from the use of the word "visible" in the definitional article $2 / 12$ / and as it is made explicit in Article 6(1) (b).

Article 15 of TRIPS provides a broader definition for trademark which seems to include the protection of both visible and non visible signs and infact, while the visibility requirement is a qualification of signs that could be considered trademarks under Ethiopian law; the TRIP agreement has the potential to require the protection of invisible signs.

To this effect, the position of Ethiopian Trademarks proclamation is not in conflict with TRIPS. According to Article (15) of the TRIPS: "... members may require, as a condition of registration, that signs be visually perceptible".

However, Contrary to Ethiopian Trademarks proclamation, several jurisdictions around the world are clearly protecting sound mark and according to the questionnaire [WIPO Questionnaire on Trademark Law and Practice, as presented in WIPO document, ${ }^{4} 38$ out of 76 countries responding said that they accepted musical sounds and 28 out of 73 countries responding said that they accepted non-musical sounds for registration as trademark. ${ }^{5}$

\footnotetext{
1 See Graeme B. Dinwoodie, \& Mark D. Janis, Trademark and Theory, a hand book of contemporary research, (2008) p. 324-345

2 William M. Landes \& Richard A. Posner, Trademark Law: An Economic Perspective, 30 J. L. \& ECON. 265 (1987)

3 Supra note 1 Article 2/12/

Standing Committee on the Law of Trademarks, Industrial Designs and Geographical Indications, Sixteenth Session, Geneva, 13-17 November2 006, New Types of Marks, ANNEX, p.8

5 It should be noted that there are two kinds of sound marks: musical and non-musical. Musical sounds which are more acceptable by countries around the world, may be either purposely created (i.e., specially commissioned) or taken from the range of existing musicals cores. Non-musical sounds may also be created or simply reproduce sounds found in nature (e.g., thunder or a lion's roar). WIPO Standing Committee on the Law of Trademarks, Industrial Designs and Geographical Indications (SCT) agreed that: with regard to an application for the registration of a sound mark, Offices may require that the representation of such marks consist of a musical notation on a stave, or a description of the sound constituting the mark, or of an analog or digital recording of that sound, or of any combination thereof. Where electronic filing is available, an electronic file [such as MP3 or WAV (Wave form audio format)] may be submitted with the application. (See Standing Committee on the Law of Trademarks, Industrial Designs and Geographical Indications Twentieth Session Geneva, 1-5 December
} 
In the case of tennis balls on 11 February 1999 the Board of Appeal of the Office for the Harmonization in the Internal Market OHIM stated that: "the smell of freshly cut grass is a distinct smell which everyone immediately recognizes from experience. For many, the scent or fragrance of freshly cut grass reminds them of spring, or summer, manicured lawns or playing fields, or other such pleasant experiences. The Board is satisfied that the description provided for the olfactory mark sought to be registered for tennis balls is appropriate and complies with the graphical representation requirement of Article 4 CTMR." 1

Given the existence of different countries who have protected sound mark explicitly, as different from Ethiopia, and the position of the Standing Committee on the Law of Trademarks, Industrial Designs and Geographical Indications, it seems that this disclaimer on what may constitute a mark under Article 2/12/ does not properly consider the new means of communication that technology is continuously introducing in modern life.

And in that a higher minimum standard should certainly have been provided for in TRIPS or at least the possibility of restricting what may constitute a mark should have been avoided. But that is not really the case since members may require, as a condition of registration, that signs be visually perceptible.

Similarly, it can be said that there seems to be no good reason, apart from possible practical difficulties of registration, for ruling out the use of sound or smell as a trademark. And it is the opinion of this writer that the Ethiopian lawmaker should have noted the use of Nokia's or Samsung's or Huawei's default ringtone and smell of fresh cut grass for tennis balls discussed above. ${ }^{2}$

\subsection{Well Known marks}

Well-known marks are marks that are considered to be well-known by the competent authority of the country where protection for the mark is sought. Well-known marks generally benefit from stronger protection. For example, well-known marks may be protected even if they are not registered (or have not even been used) in a given territory. ${ }^{3}$

when we see the wording of Article $6^{\text {bis }}$ section 1 of the Paris convention, it Principally provides the protection of well known mark and requires the member countries to refuse or to cancel the registration, and to prohibit the use, of a trademark which constitutes a reproduction, an imitation, or a translation, liable to create confusion, of a mark considered by the competent authority of the country of registration or use to be well known in that country. ${ }^{4}$

However Article 16.2 sentence 1 of TRIPS expands the protection under Art. $6^{\text {bis }}$ Paris convention to services. Accordingly, Members are obliged to protect a service mark registered only abroad against the registration in their national territory by way of denial of registration or cancellation and prohibition of use. ${ }^{5}$

To legally protect unregistered well-known trademarks with respect to identical and (or) similar goods and services, Member States in their national legislation are using the wording analogous or similar to the wording of Art. $6^{\text {bis }}$ of the Paris Convention and (or) Article 16(2) of the TRIPS Agreement. In that regard, unregistered well-known trademarks can be protected with respect to identical and (or) similar goods and services if there is a likelihood of confusion. ${ }^{6}$

Despite this however, unlike providing two basic objective assessment criteria's for member states, ${ }^{7}$ neither the Paris Convention nor the TRIPS Agreement, provides a definition of well-known trademarks and hence, it is up to the Members to identify when a trademark is to be considered well-known.

Similarly member states should grant protection of well-known mark though there is no product or service similarity if three conditions are fulfilled cumulatively under Article 16/3/ of TRIPS. These are the well known mark should be registered. Second, the use of the conflicting trademark must indicate a connection to the goods and services of the owner of the well-known trademark. Thirdly, interest of the owner of the well-known

2008, Representation of Non-Traditional Marks Areas of Convergence, document prepared by the Secretariat, Annex, P.4.)

${ }^{1}$ See Luca Escoffier \& Arnold Jin, To scent, or not to scent, that is the question: a comparative analysis of olfactory trademarks in the EU and US as good brand opportunities for SMEs http://www.wipo.int/sme/en/newsletter/2011/attachments/olfactive trademarks.doc (last accessed on $10 / 3 / 2019)$

${ }^{2}$ Ibid

3 Supra note 15 at 17

${ }^{4}$ Paris Convention for the Protection of Industrial Property (of March 20, 1883, as revised at Brussels on December 14, 1900, at Washington on June 2, 1911, at The Hague on November 6, 1925, at London on June 2, 1934, at Lisbon on October 31, 1958, and at Stockholm on July 14,1967 , and as amended on September 28, 1979) [here in after called PC or the Paris convention interchangeably] Article 6bis section 1

See Peter Tobias Stoll, Jan Bushe, and Katrin Arend Max Plank commentaries on World Trade Law (WTO): Trade Related Aspects of Intellectual property Rights, (2008), p. 323

${ }^{6}$ Danguole Klimkevičiūte, the legal protection of well known trademarks and trademarks with reputation: The trends of the legal regulation in the EU member states, Social Sciences Studies. 2010, 3(7): 229-256.

7 The First assessment criteria in granting the protection to well-known mark required members to look for the "knowledge of the trademark in the relevant sector of the public." Secondly, TRIPS specifies the concept of well-known trademarks by permitting the knowledge in the Member to be "obtained as a result of the promotion of the trademark." And in that, the trademark need not actually be used, but it is sufficient that mark is advertised. (for more see Plank commentaries on World Trade Law, supra note 23 p 324 ) 
trademark is likely to be damaged by the use of the conflicting mark.

Given the above discussion on well known marks as enshrined in either the TRIPS or Paris Convention, it can be said that the trademark proclamation is not far away from the international arena in protecting wellknown marks.

This is because, even if it fails to define as though they were in its international counterpart, the proclamation accepts the protection of well-known marks under Article 23 up on the fulfillment of the following cumulative requirements.

First, a trademark which is entitled to protection must be a well-known trademark under an international convention to which Ethiopia is a party. ${ }^{1}$ Second, it must be well known to Ethiopia too. And thirdly, it should be a trademark of a person (whether or not such person carries on business or has any good will in Ethiopia) who is the national of a state party to the convention which Ethiopia is a party, or domiciled in or has a real and effective industrial or commercial establishment in a state party to the convention. ${ }^{2}$ Sub Article 2 of Article 23 of the proclamation provides objective criteria's for assessing well-known as similar to that of the TRIPS system. ${ }^{3}$

Looking to this provision of the proclamation, it appears that the legislature wants to privilege well-known marks. This is because on the one hand Article 4 of the proclamation explicitly provides that "ownership of a trademark is acquired and be binding on third parties upon the grant of a trademark registration certificate", and on the other hand it seems that the proclamation protects well-known marks though not registered, but a 'well known' at a convention to which Ethiopia is a party and based on the requirements discussed above.

This raises a question as to what kind of regulation that Ethiopia is trying to consist with well known mark. (i.e. whether or not the proclamation allows the owner of well known marks to invalidate registered marks in favor of others?)

The writer argues that even if registration is necessary for trade mark protection under Article 4 of the proclamation the owner of well known mark, up on establishing that 'the mark is well known' under the convection to which Ethiopia is a party and other requirements discussed above, can claim protection of the well-known mark.

This is because on the one hand Ethiopia clearly protects well known mark under Article 23 not because the mark is registered as per Article 4, rather it is well-known mark, and on the other hand as the proclamation is enacted after the application for accession of the WTO it seems that Ethiopia wants to make its trademark laws compatible with the Article $6^{\text {bis }}$ and Article 8 \& Article 16/2/3/ of Paris Convention as far as the protection of well known mark is concerned.

However, unlike putting the idea that well-known mark is simply protected under Article 23, it is not clear from the proclamation what type of protection it meant to give for unregistered well known mark given Article 4/1/ and Article 26 and the following provisions were dealing specifically about registered marks.

In U.S.A. for example protection for well-known trademarks has been provided under the Federal Trademark Dilution Act of 1995. Article 43(c) (1) provides that:

"The owner of a famous mark shall be entitled, subject to the principles of equity and upon such terms as the court deems reasonable, to an injunction against another person's commercial use in commence of a mark or trade name, if such use begins after the mark becomes famous and causes dilution of the distinctive quality of the famous mark, and to obtain such other relief as is provided in this subsection." 4 This provision of the US gives the owner of well-known mark to seek an injunctive relief or any other relief as provided in there in.

However, even if there is no clear stipulation as though they were in the US Lanham Act, the Ethiopian trademark proclamation recognizes under Article 26/4/ the right of the owner of a well known mark and incase the owner institute an action for infringement the provisions of Article 26/3/ apply to the owner of well known mark.

Given the fact that Ethiopia is on the process of acceding to WTO, and the very essence that it has to consider the right provided for the owner of well-know mark under international instruments, it can be said that if the owner of well known mark can establish that the mark is famous or well known elsewhere in the world, and 'well-known' within the meaning of Article 23 of the proclamation, the owner can request for refusal or cancellation of registration, and request to prohibit the use of a trademark as provided under Article $6^{\text {bis }}$ section 1 and Article 16/2/3/ of the TRIPS agreement.

\footnotetext{
1 See the criteria's for determining well known marks provided by Joint Recommendation Concerning Provisions on the Protection of WellKnown Marks, Thirty-Fourth Series of Meetings of the Assemblies of the Member States of WIPO September 20 to 29, 1999 , World Intellectual Property Organization Geneva 2000

2 Trade mark proclamation, supra note1 Article 23/1/

3 See supra note 25

${ }^{4}$ See the Federal Trademark Dilution Act of 1995. Article 43(c) (1) of the US Lanham Act
} 


\subsection{Collective Marks}

These are the other marks that are protected under our proclamation together with visible marks and well known marks. Accordingly collective mark is a mark distinguishing the goods or services of members of the association which is the proprietor of the mark from those of other undertakings.

The association generally establishes a set of criteria for using the collective mark (e.g., quality standards) and permits individual companies to use the mark if they comply with such standards. Collective marks may be an effective way of jointly marketing the products of a group of enterprises which may find it more difficult for their individual marks to be recognized by consumers and/or handled by the main distributors. ${ }^{1}$

The main feature of a collective mark is that it is used as an indication to the relevant public that goods or services originate from a member of a particular association. It is therefore a sign of membership. ${ }^{2}$

As far as the international protection of collective mark is concerned as early as 1911, the protection of collective marks was introduced into the Paris Convention for the Protection of Industrial Property (Paris Convention). Article 7bis, which was introduced by the Revision Conference of Washington in 1911 and further elaborated by the Revision Conference of London in 1934 provided that the countries of the Union undertake to accept for filing and to protect collective marks belonging to associations, the existence of which is not contrary to the law of the country of origin, even if such associations do not possess an industrial or commercial establishment. ${ }^{3}$ Collective marks can be and is used to protect geographical indications. ${ }^{4}$

To ensure consistency with Article $7^{\text {bis }}$ of the Paris Convention, States parties should enact a legislation concerning the protection of collective marks. Subsequently, (WTO) members were also required to provide protection for such marks by virtue of Article 2 of the TRIPS Agreement.

Ethiopia, being applying for the WTO and on the move to this global system of trade, seems to realize the fact that its laws should be compatible with the TRIPS which in effect, in my opinion, includes provisions protecting collective mark as though they were in the Paris convention.

To this effect, Article 18 and the following provisions provide for the protection of collective mark and in that Article 2 defines collective trademark as:

"Collective trademark means a trademark distinguishing the goods or services members of an association, which is the owner of the trademark, from those of other undertakings",

Accordingly as per Article 18 of the proclamation, for a collective trade mark to be protected there must be an application and application shall designate the trade mark as "collective trademark" and shall be accompanied by the copy of the statute ${ }^{345}$ the governing the use of such trademark.

And the person's eligible to apply for collective Trademark as exhaustively listed under Article 19 of the proclamation is limited to Trade union, Trade union federations or association.

\section{Requirements for Protection of Trade Mark in Ethiopia}

It is true that Art. 15.1 of the TRIPS agreement limited the right of Members to determine the conditions of registration of trademarks under their domestic legislation pursuant to Article 6(1) of Paris Convention only as it related to the distinctiveness requirements under Article 15.1. It did not impose an obligation to file and register each and every mark.

Accordingly, members have the right to lay down their own national conditions, as long as they are compatible with 15 sections 1-4 of TRIPS and Art. 6.1 Paris Convention. ${ }^{6}$

For this reason, distinctiveness of signs seems to be at the heart of the requirement for protection under both the Ethiopian trademark law and the TRIPs agreement. This is because the main bench mark that both laws require (the proclamation under article 5 and article 15 (1) of the TRIPs agreement) is distinctiveness of the sign.

Distinctiveness could be defined as the inherent capacity of a trademark to be perceived by the market participants as a means to distinguish the goods or services of an undertaking from those of other undertakings, thus allowing the attribution of these goods or services to a particular commercial origin. ${ }^{7}$

\footnotetext{
${ }^{1}$ Business series No. 1 supra note 13

See Certification and collective marks-Paper prepared by the United Kingdom for the SCT http://www.wipo.int/export/sites/www/sct/en/comments/pdf/sct21/cert_uk.pdf (last accessed on 17/01/2019)

3 Standing Committee on the Law of Trademarks, Industrial Designs and Geographical Indications, technical and procedural aspects relating to the registration of certification and collective mark, WIPO/STrad/INF/6 2010 p.3

${ }^{4}$ See TRIPS Module IV on geographical indication

https://www.wto.org/english/tratop e/trips e/ta docs e/modules4 e.pdf (last accessed on 17/01/2019)

${ }^{5}$ The contents of the statute here, is provided under Article 18/3/ of the trademark proclamation.

${ }^{6}$ The author thinks that distinctiveness within the meaning of article 15 of the TRIPS should be seen in two different points of views. If the sign is inherently distinctive and capable of distinguishing the goods and services, then member states shall afford protection by the mere fact that it is distinctive. However, if the mark is not inherently distinctive or inherently distinctive but incapable of distinguishing the goods and services then members may make registerability based on distinctiveness acquired through use. (See also Max Plank commentaries on World Trade Law, supra note 23 p. 313 and 310 )

${ }^{7}$ Standing Committee on the Law of Trademarks, Industrial Designs and Geographical Indications, Grounds For Refusal of All types of

Marks, document prepared by the Secretariat, WIPO/STrad/INF/5 Aug. 30, 2010 p. 8
} 
The fact that distinctiveness of signs is a core part of the Ethiopian trademark law is also envisaged from Article 6/3/ which provides that "protection is given for a mark which includes elements that are not subject to protection, but did not decrease the distinctive elements...." and from Article 6/1/c/ which makes signs "incapable of distinguishing the goods or services of one person from those of other persons" inadmissible for trademark registration".

Accordingly, it can be said from this provisions that the legislature wants to provide distinctive element as the very criteria for the of protection trademark in Ethiopia. And this move of the Ethiopian legislature is compatible with TRIPS system.

When is said to be a trademark is distinctive?

Distinctive trademarks share three qualities. First, they are different from other marks used to describe similar goods and services. Second, they are not merely descriptive of the type of good or service. Third, they are recognized as identifying the source of the good or service.

A trademark is said to be considered distinctive if it is recognized by a sufficiently large part of the relevant public as a mark of one single trader. In some jurisdictions, evidence of use is a factor in determining whether a mark has become distinctive. The evidence includes opinion polls, surveys, and statements from trade and consumer organizations, articles, brochures, samples, evidence of turnover and advertising, and other types of promotion and of successful prosecution of infringers.

In addition it is important to show examples of how the mark is used (brochures, packaging, etc.), the length of use and the amount (volume) of use, which is of particular relevance. Also, use must be of the trademark applied for and not of a significantly different variation, and the use must relate to the goods and services which are the subject of the trademark application. ${ }^{1}$

\section{Exclusive Rights of the owner}

Art. 16.1 provide the trademark owner with a guaranteed minimum protection. It establishes protection beyond the prior existent system of international trademark law conventions as it guarantees "exclusive rights" to trademark owners that were so far limited to protection against unfair competition under Art. $10^{\text {bis }} / 3 /$ of Paris Convention. In his book, peter explained the exclusive right of the owner provided under Article 16.1 saying that the owner is granted with both a protection of the trademark's identity and a protection against confusion. ${ }^{2}$

Thus, the trademark owner has the right to prevent other people from using the same mark or confusingly similar mark with respect to the same product or confusingly similar product.

Such right of preventing others under Article 16.1 will have effect only if there is a 'likelihood of confusion' among consumers of the product or service in question. The existence of a 'likelihood of confusion' will be presumed if the sign used is identical to the registered trademark or if the good or service is the same as one for which the trademark is registered for.

A similar right is granted under the Ethiopian trademark proclamation. A combined reading of article 26 sub-article 1 and 2 would provide the same rights that are enshrined under the TRIPs agreement.

Accordingly, the owner of a trademark has the exclusive "right to use or authorize any other person to use the trademark" (A positive right) and also have a negative right to prevent if the use of a sign is likely to confuse consumers of the product or service in question about the source of the product or service.

However, article $26(2, \mathrm{~b})$ of the proclamation provides an extended right than granted under the TRIPs agreement. It gives the owner the right to exclude others from using the sign (or similar signs) in any way that is "likely to be prejudicial to his interests" even if there is no likely hood of confusion. And in fact, this may open the door for the owner to seek unnecessary protection without their being any confusion on the part of the mark and the product or service to which the mark is registered. In particular, it seems that the owner of Anchor milk or St George beer can prohibit the use of Anchor for furniture products or St Gorge for football clubs.

It is the opinion of the author that Article 26/2/b/ and /c/ should be interpreted together with the purpose for which the protection is given. Trademark protection is not a protection of creation just like inventions or it is not a protection of expression of ideas. It is rather the protection of the producer from unjust usage of the mark against the product and service for which the mark registered and unfair competition, and of course, the protection of the consumers from confusions and reduction of the search cost of consumers.

Given this truth however, it can be said that the protection provided under Article 26/2/b/ and /c/ is meant to protect the owner and consumer not the mark and thereby in my opinion, these provisions are not intended to protect the owner of Anchor milk or St George beer to prevent the use of Anchor for furniture products or St Gorge for football clubs.

\footnotetext{
${ }^{1}$ Standing Committee on the Law of Trademarks supra note $35 \mathrm{p} 33$

2 see Max Plank commentaries on World Trade Law, supra note 23 p. 318
} 


\section{Concluding Remarks}

To sum up, given new technologies and innovations, increasingly, countries of the world have included protection to non-traditional trademarks in their trademark laws, and there seems to be no good reason, apart from possible practical difficulties of registration, for ruling out the use non-conventional mark as a trademark. And it is the opinion of the writer that the Ethiopian lawmaker should consider the amendment of the proclamation to include non-conventional marks.

Similarly, the trademark proclamation, though it provides protection for well-known marks and a cross reference is provided in case of infringement under article 26/3/ it is not as clear as what's provided under the Lanham act of the US regarding the owner of well-known mark trademark owner whose right is infringed. Thus it is better, in my opinion to provide provisions dealing with infringement of well known mark separately in the proclamation to attract the WTO negotiating team and members in this regard.

Despite the above remarks however, the Ethiopian trademark proclamation, is compatible and there are even TRIPS plus provisions the possibility of which the above recommendations would be unlikely to be noticed by the WTO negotiating team given Ethiopia's accession team's ability to convince, and thereby the recommendations may be used to have a well organized trademark law that could answer issues that might be raised in the future. 